\title{
Benzimidazole Schiff base derivatives: synthesis, characterization and antimicrobial activity
}

Thierry Youmbi Fonkui ${ }^{*}$, Monisola Itohan Ikhile², Patrick Berka Njobeh ${ }^{1}$ and Derek Tantoh Ndinteh ${ }^{2}$

\begin{abstract}
A series of Schiff bases (3.a-f) bearing benzimidazole moiety was successfully synthesized in ethanol by refluxing Oct2-ynoic acid (1,3-dihydrobenzimidazole-2-ylidene)amide with substituted amines. Fourier transform infrared (FTIR), ultra violet light (UV-VIS), elemental analysis, proton $\left({ }^{1} \mathrm{H}\right)$ and carbon $\left({ }^{13} \mathrm{C}\right)$ nuclear magnetic resonance spectroscopy were used to characterize the newly synthesized Schiff bases. Micro dilution method was used to determine the minimum inhibitory concentration (MIC) and minimum fungicidal concentration (MFC) of the Schiff bases, against 14 human pathogenic bacteria ( 8 Gram negative and 6 Gram positive) and against 7 fungal strains (5 Aspergillus and 2 Fusarium) representatives. Antimalarial activity against Plasmodium falciparum and antitrypanosomal property against Trypanosoma brucei was studied in vitro at a single dose concentration of the Schiff bases. Cytotoxicity of the Schiff bases was assessed against human cervix adenocarcinoma (HeLa) cells. Results obtained show that the newly synthesized Schiff bases are very potent antimicrobial agents. Gram negative bacteria Klebsiella pneumonia and Escherichia coli were more affected on exposure to Compounds 3.c-f (MIC $7.8 \mu \mathrm{g} / \mathrm{mL}$ ) which in turn exhibited more antibacterial potency than nalidixic acid reference drug that displayed MICs between 64 and $512 \mu \mathrm{g} / \mathrm{mL}$ against K. pneumonia and E. coli respectively. The test compounds also demonstrated high cytotoxic effect against Aspergillus flavus and Aspergillus carbonarius as they displayed MFC 7.8 and $15.6 \mu \mathrm{g} / \mathrm{mL}$. Compound 3.c exhibited the highest fungicidal property from this series with MFC alternating between 7.8 and $15.6 \mu \mathrm{g} / \mathrm{mL}$ against the investigated strains. The malarial activity revealed Compounds 3.c and 3.d as the more potent antiplasmodial compounds in this group exhibiting 95\% and $85 \%$ growth inhibition respectively. The $I C_{50}$ of Compounds $\mathbf{3 . c}$ and $\mathbf{3 . d}$ were determined and found to be $\mathrm{IC}_{50} 26.96$ and $28.31 \mathrm{\mu g} / \mathrm{mL}$ respectively. Compound 3.a was the most cytotoxic agent against HeLa cells in this group with $48 \%$ cell growth inhibition. Compounds 3.c, 3.d and 3.f were biocompatible with HeLa cells and displayed low toxicity. With a very low cytotoxic effect against HeLa, compound 3.c stands out to be a very good antiparasitic agent and consideration to further evaluate the candidate drug against others cell lines is necessary.
\end{abstract}

Keywords: Schiff bases, Benzimidazole, Antibacterial, Antifungal and antiparasitic activity

\section{Introduction}

Fungi, bacteria, parasites, and viruses are at the forefront of the global health challenges as they continue to nullify the potency of many antimicrobial agents [1]. From the literature, it is clear that significant efforts to remedy

\footnotetext{
*Correspondence: thierryfy@uj.ac.za

${ }^{1}$ Department of Biotechnology and Food Technology, University

of Johannesburg, Doornfontein Campus, P.O. Box 17011,

Johannesburg 2028, South Africa

Full list of author information is available at the end of the article
}

the situation are available however, none can deny the current problem of microbial resistance. The prevalence of these microorganisms is a concern because of adaptations and mutations, the selectivity of the novel developing drugs and the toxicity effect of certain candidate drugs. Infections by these microorganisms affect the health status of the consumers or the host organisms that may result in loss of human life and livestock's. This therefore encourages the continuous search for novel compounds with enhanced bioactive properties. 
Schiff bases are an important class of organic compounds that show interest in industrial sectors with many biological and pharmaceutical applications. They are usually obtained by a condensation reaction between aldehydes or ketones (cyclic or linear) with primary amines (cyclic or linear) in alcoholic conditions [2]. Interest in the search for novel therapeutic Schiff bases to alleviate pathogens invasion associated with microbial resistance encourage the use of cyclic ring molecules. Aromatic-based Schiff bases have shown more potential in biological applications as a result of the free electron delocalization with the ring structure [3]. Schiff bases derived from heterocyclic rings present many advantages and detailed information are found here [4]. The most predominant heteroatoms found in organic molecules are mainly nitrogen, oxygen, and sulfur $(\mathrm{N}, \mathrm{O}, \mathrm{S})$.

Nitrogen-containing heterocyclic compounds such as imidazole and benzimidazole form a framework of the important class of pharmacophores [5]. They have attracted the attention of many researchers as their derivatives astemizole, mebendazole, enviroxime, carbendazime have been widely used and also commercialized $[6,7]$. Benzimidazole on its own alone is a benzo derivative of imidazole used in the development of therapeutic drugs. Its fused heterocyclic ring structure is crucial to the formation of nucleotides as they formed the nucleus of nitrogen bases [5]. Benzimidazole and its derivatives interact easily with biopolymers and promise to be forming good systems for the development of biologically active compounds with structural similarity to vitaminB12 derivatives [8]. The fascinated biological activity of benzimidazole and its derivatives are seen against many human pathogens and microbial attacks. These include bacteria [9], fungi [10], and virus [11]. Schiff bases with benzimidazole moiety have also been used in DNA binding and cleavage [12, 13], they are also documented as topoisomerase inhibitors [14], with antitumor [15], and anticancer properties [16]. Their parasitic and viral properties cannot be denied as previously documented [17].

In our search for more dependable antimicrobial agents to limits microbial invasion and resistance to known drugs, we have synthesized a series of novel Schiff bases with benzimidazole scaffold and evaluated their antimicrobial activity against 14 bacterial strains, seven fungal strains and two parasites representative (Plasmodium falciparum and Trypanozoma brucei).

\section{Results and discussion \\ Chemistry}

Schiff base compounds 3.a-f were synthesized according to the procedure shown in Scheme 1. Oct-2-ynoic acid (1,3-dihydrobenzoimidazole-2-ylidene)amide (Compound 1) was used as the starting material. Spectral measurements including UV-VIS absorption, Fourier transform infrared (FTIR), nuclear magnetic resonance proton and carbon $\left({ }^{1} \mathrm{H}\right.$ and ${ }^{13} \mathrm{C}$ NMR $)$ and $\mathrm{C}, \mathrm{H}, \mathrm{N}$ elemental analysis were used to characterize and establish the structure of the prepared ligands.

Table 1 shows the physicochemical property of the Schiff bases together with their melting points and lipophilicity indexes determined on ChemDraw Ultra 7.0.

\section{Electronic spectral}

All the synthesis were carried out by mixing Compound $1(0.3921 \mathrm{mmol})$ with aniline derivatives $(0.3921 \mathrm{mmol})$ in the presence of hot ethanoic solution and reflux for $4 \mathrm{~h}$ to give the expected Compounds 3.a-f. In order to study the spectroscopic properties of the ligands, their UV-VIS absorption spectra were recorded in DMSO and are presented in Fig. 1.

The normalized UV-VIS spectra of the compounds (Table 2) exhibit two absorption bands in low UV range (232-290 nm) except Compound 3.e that presents an additional band at $410 \mathrm{~nm}$. The bands observed below $250 \mathrm{~nm}$ are assigned to the $\pi-\pi^{*}$ transition of azomethine<smiles>[R]c1c([R])c([R])c(N=C(C#CCCCCC)N=c2[nH]c3ccccc3[nH]2)c([R])c1[R]</smiles>

Scheme 1 Synthesis of Schiff bases 3.a-f under (i) $4 \mathrm{~h}$ refluxing in ethanol 
Table 1 Chemical property of the synthesized Schiff bases 3.a-f

\begin{tabular}{|c|c|c|c|c|c|c|c|c|c|c|c|}
\hline \multirow[t]{2}{*}{ Carbonyl } & \multicolumn{6}{|c|}{ Amines } & \multirow[t]{2}{*}{ Product } & \multirow[t]{2}{*}{$\mathrm{MW}(\mathrm{g} / \mathrm{mol})$} & \multirow[t]{2}{*}{ Yield (\%) } & \multirow[t]{2}{*}{ Mpt $\left({ }^{\circ} \mathrm{C}\right)$} & \multirow[t]{2}{*}{$c \log P$} \\
\hline & $\mathrm{R}_{1}$ & $\mathbf{R}_{2}$ & $\mathbf{R}_{\mathbf{3}}$ & $\mathbf{R}_{\mathbf{4}}$ & $R_{5}$ & $x$ & & & & & \\
\hline & $\mathrm{NO}_{2}$ & $\mathrm{H}$ & $\mathrm{H}$ & $\mathrm{H}$ & $\mathrm{H}$ & $C$ & $3 . a$ & 375.42 & 78 & 178.7 & 5.09 \\
\hline & $\mathrm{OH}$ & $\mathrm{H}$ & $\mathrm{H}$ & $\mathrm{H}$ & $\mathrm{H}$ & $C$ & 3.b & 346.43 & 46 & $136-137$ & 4.68 \\
\hline & - & $\mathrm{H}$ & $\mathrm{H}$ & $\mathrm{H}$ & $\mathrm{H}$ & $N$ & $3 . c$ & 331.41 & 63 & 172.1 & 3.85 \\
\hline 1 & $\mathrm{H}$ & $\mathrm{H}$ & $\mathrm{COOH}$ & $\mathrm{H}$ & $\mathrm{H}$ & $C$ & 3.d & 374.44 & 73 & 175.2 & 5.09 \\
\hline & $\mathrm{OH}$ & $\mathrm{H}$ & $\mathrm{SO}_{3} \mathrm{H}$ & $\mathrm{H}$ & $\mathrm{H}$ & $C$ & 3.e & 426.49 & 64 & 147.1 & 1.9 \\
\hline & $\mathrm{OCF}_{3}$ & $\mathrm{H}$ & $\mathrm{H}$ & $\mathrm{H}$ & $\mathrm{H}$ & $C$ & $3 . f$ & 414.17 & 67 & $178-180$ & 6.38 \\
\hline
\end{tabular}

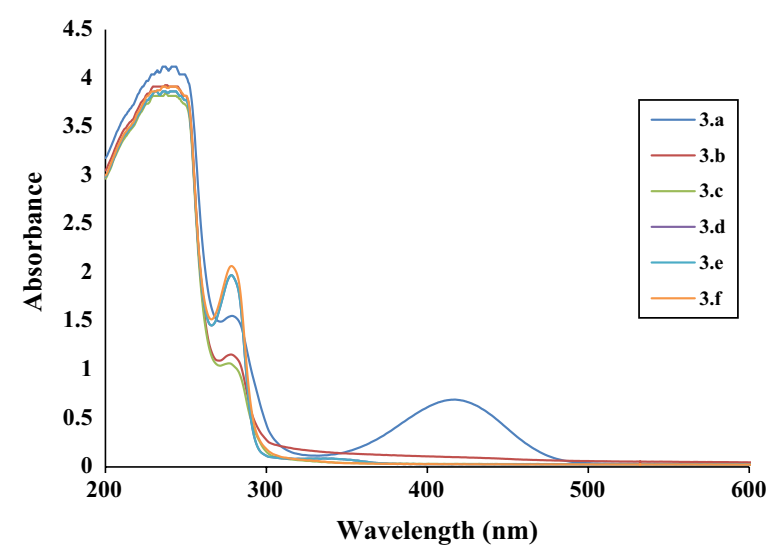

Fig. 1 UV-vis absorption spectra of Schiff bases 3.a-f

chromophore and above $250 \mathrm{~nm}$ are the typical $n-\pi^{*}$ transitions of charge transfer between $\mathrm{C}=\mathrm{N}$ of the ligands [3]. The band at $410 \mathrm{~nm}$ observed in Compound 3.e happened to be coming from the $\mathrm{HSO}_{3}$-of the aromatic ring because of the free electron distribution (Table 2).

\section{Fourier transform infrared}

IR spectra of this series of Schiff bases showed vibration signals at expected frequencies for the relevant functional moieties and chromophores (Table 3). The stretching frequencies at $1652-1685 \mathrm{~cm}^{-1}$ are due to the imine $(\mathrm{C}=\mathrm{N})$ linkage of the ligands and match similar observation here

Table 2 UV-vis spectroscopy of the synthesized Schiff bases 3.a-f

\begin{tabular}{lll}
\hline Compounds & $\begin{array}{l}\text { Absorption band } \\
(\mathbf{n m})\end{array}$ & Assigned transitions \\
\hline 3.a & $232-275$ & $\pi-\pi^{*}$ and $n-\Pi^{*}$ \\
3.b & $234-286.5$ & $\pi-\pi^{*}$ and $n-\pi^{*}$ \\
3.c & $234-284$ & $\pi-\pi^{*}$ and $n-\pi^{*}$ \\
3.d & $235-275$ & $\pi-\pi^{*}$ and $n-\pi^{*}$ \\
3.e & $234-410$ & $\pi-\pi^{*}$ and $n-\pi^{*}$ \\
3.f & $233-285$ & $\pi-\pi^{*}$ and $n-\pi^{*}$ \\
\hline
\end{tabular}

[7]. Characteristic vibration signals proper to the $\mathrm{C}-\mathrm{H}$ stretching band of the aromatic ring were observed at 2955-3000 $\mathrm{cm}^{-1}$ with low intensity. Sharp bands present in the spectrum of the compounds, in the region $3297-1500 \mathrm{~cm}^{-1}$ are due to $\mathrm{N}-\mathrm{H}$ stretching frequencies of imidazole moiety [18]. The vibration of $\mathrm{C}=\mathrm{O}$ and $\mathrm{S}=\mathrm{O}$ of Compounds 3.d and 3.e are seen around $2231 \mathrm{~cm}^{-1}$. In the spectra, no signal characteristic to the $-\mathrm{NH}_{2}$ of the primary amine was observed and this implies the successful formation of the Schiff base ligands.

\section{Nuclear magnetic resonance spectroscopy}

The carbonyl used in the condensation reaction was a ketone and no imine proton was observed in the spectra of the Schiff bases characterized. The ${ }^{1} \mathrm{H}$ NMR of these compounds showed both aliphatic and aromatic protons $(\mathrm{Ar}-\mathrm{H})$. Aromatic protons resonate at single, doublet and multiplet at chemical shift $\delta=6-7 \mathrm{ppm}$ with respect to the aromatic group. However, in these compounds other $\mathrm{Ar}-\mathrm{H}$ proton were seen around $\delta=8 \mathrm{ppm}$ (Compounds 3.a, 3.c and 3.f) by reason of electron rich species on the substituted rings which in turn causes an increase in the chemical shift of the proton and result in the deshielding effect. Phenolic protons are seen at chemical shift $\delta=8.2 \mathrm{ppm}$ for Compound 3.b and at $\delta=10.10 \mathrm{ppm}$ for Compound 3.e as expected. Around $4 \mathrm{ppm}$ chemical shift the $\mathrm{N}-\mathrm{H}$ signals of the benzimidazole ring are seen. Protons of the aliphatic side chain appear as doublet, triplet and multiplet in low range chemical shift $(0.8-2 \mathrm{ppm})$ with no traces of contamination. The ${ }^{13} \mathrm{C}$ NMR spectra, $\mathrm{C}=\mathrm{N}$ signals of the benzimidazole ring and imine of the synthesized Schiff bases were observed around $\delta=158-159 \mathrm{ppm}$ as expected. Aromatic carbons are seen at $\delta=108-140 \mathrm{ppm}$ and the alkyne carbon resonate at $\delta=70-80 \mathrm{ppm}$. All aliphatic carbons were seen at $\delta=13-30 \mathrm{ppm}$ with $\mathrm{C} \equiv \mathrm{C}-\mathrm{CH}_{2}$ resonating around $\delta=30 \mathrm{ppm}$.

The experimental percentage composition $\mathrm{C}, \mathrm{H}, \mathrm{N}$ of the prepared Schiff bases obtained were corresponded to the calculated data as confirmed by a difference of \pm 0.6 unit seen in the recorded data. 
Table 3 FTIR spectroscopy of the synthesized Schiff bases 3.a-f

\begin{tabular}{|c|c|c|c|c|c|c|c|}
\hline Compounds & $\mathrm{v}(=\mathrm{C}-\mathrm{H})\left(\mathrm{cm}^{-1}\right)$ & $\mathrm{v}(\mathrm{C}-\mathrm{N})\left(\mathrm{cm}^{-1}\right)$ & $\mathrm{v}(\mathrm{C}-\mathrm{C})\left(\mathrm{cm}^{-1}\right)$ & $\mathrm{v}(\mathrm{N}-\mathrm{H})\left(\mathrm{cm}^{-1}\right)$ & $\mathrm{v}(\mathrm{N}-\mathrm{H})\left(\mathrm{cm}^{-1}\right)$ & $\mathrm{v}(\mathrm{C}=\mathrm{N})\left(\mathrm{cm}^{-1}\right)$ & $\mathrm{v}(\mathrm{C}-\mathrm{H})\left(\mathrm{cm}^{-1}\right)$ \\
\hline 3.a & 950 & 1011 & 1435 & 1438 & 3414 & 1652 & 3000 \\
\hline 3.b & 825 & 1030 & 1359 & 1550 & 3370 & 1677 & 2959 \\
\hline $3 . c$ & 950 & 1034 & 1443 & 1501 & 3423 & 1685 & 2982 \\
\hline 3.d & 817 & 1034 & 1371 & 1559 & 3666 & 1684 & 2955 \\
\hline 3.e & 820 & 1033 & 1370 & 1541 & 3297 & 1678 & 2966 \\
\hline $3 . f$ & 956 & 1035 & 1419 & 1443 & 3431 & 1685 & 2975 \\
\hline
\end{tabular}

\section{Pharmacological activity Antibacterial activity}

In vitro antibacterial activity of Schiff base compounds (3.a-f) were studied against six Gram positive and eight Gram negative bacteria using broth microdilution technique. The minimum inhibitory concentrations (MIC) of the compounds were compared to streptomycin and nalidixic acid used as reference antibiotic agents and data are presented in Table 4. Tested organisms reacted differently to ligands exposure and their susceptibility was concentration dependent. Test compounds exhibited good to high antibacterial activity against different bacterial representatives. For instance, Staphylococcus epidermidis was the most susceptible strain amongst the Gram positive under studied exhibiting MIC between 7.8 and $15.6 \mu \mathrm{g} / \mathrm{mL}$ and appears to be 8.5 times more potent than nalidixic acid (MIC $64 \mu \mathrm{g} / \mathrm{mL}$ ). Compounds 3.a-c and 3.f displayed greater antibacterial activity (MIC $31.2 \mu \mathrm{g} /$ $\mathrm{mL}$ ) against Staphylococcus aureus than streptomycin (MIC $256 \mu \mathrm{g} / \mathrm{mL}$ ). Gram negative bacteria Klebsiella pneumonia and Escherichia coli were more affected on exposure to Compounds 3.c-f (MIC $7.8 \mu \mathrm{g} / \mathrm{mL}$ ) which in turn exhibited more antibacterial potency than nalidixic acid that displayed MICs between 64 and $512 \mu \mathrm{g} / \mathrm{mL}$ against $K$. pneumonia and E. coli respectively. Compound 3.c exhibited the broadest spectrum activity in this series due to the heterocyclic ring of the amine.

The improved potency of these compounds could also be due to other parameters besides the imine $\mathrm{C}=\mathrm{N}$ bond. These include the benzimidazole ring and the substituted aromatic rings. Positive Gram bacteria were more sensitive to test compounds than negative Gram bacteria due to the nature of the cell membranes. The lack of activity may also be due to poor target engagement or nonessentiality of the targeted enzyme/partway in vivo [19]. The reason probably lies in the difference in cell membrane compositions. Unlike Gram-negative bacteria that have three other components outside the peptidoglycan (lipopolysaccharides, phospholipids, periplasmic space) for defence, positive Gram bacteria lack these protective coats outside peptidoglycan layer, which then make them more vulnerable to foreign attacks [20]. Resistance of bacteria to the synthesized Schiff bases could also be associated to the enzymatic degradation of the synthesized compounds, alteration of the bacterial protein targeted by the prepared compounds and/or change in the membrane permeability to the tested compounds [21]. In addition, Gram-negative bacteria are very much

Table 4 Antibacterial activity of the Schiff bases 3.a-f

\begin{tabular}{|c|c|c|c|c|c|c|c|c|c|c|c|c|c|c|}
\hline \multicolumn{15}{|c|}{ Minimum inhibitory concentration MIC $(\mu \mathrm{g} / \mathrm{mL})$} \\
\hline \multirow[t]{2}{*}{ Compounds } & \multicolumn{6}{|c|}{ Gram positive } & \multicolumn{8}{|c|}{ Gram negative } \\
\hline & BS & EF & SE & SA & $\mathrm{BC}$ & MS & $\mathrm{ECL}$ & EM & KO & EA & PM & PA & KP & EC \\
\hline 3.a & 125 & 250 & 15.6 & 31.2 & 250 & 250 & 250 & 125 & 62.5 & 250 & 250 & 250 & 15.6 & 7.8 \\
\hline $3 . b$ & 62.5 & 125 & 15.6 & 31.2 & 125 & 125 & 250 & 125 & 125 & 125 & 125 & 125 & 62.5 & 31.2 \\
\hline $3 . c$ & 125 & 125 & 7.8 & 31.2 & 125 & 125 & 125 & 125 & 125 & 125 & 125 & 125 & 7.8 & 7.8 \\
\hline 3.d & 125 & 250 & 7.8 & 250 & 250 & 250 & 250 & 250 & 31.2 & 125 & 250 & 250 & 7.8 & 7.8 \\
\hline 3.e & 125 & 125 & 7.8 & 125 & 125 & 62.5 & 250 & 125 & 62.5 & 125 & 125 & 250 & 7.8 & 7.8 \\
\hline $3 . f$ & 125 & 125 & 7.8 & 31.2 & 125 & 31.2 & 125 & 125 & 62.5 & 125 & 250 & 125 & 7.8 & 7.8 \\
\hline STM & 16 & 128 & 8 & 256 & 32 & 4 & 512 & 128 & 16 & 16 & 128 & 16 & 64 & 64 \\
\hline NLD & 16 & $>512$ & 64 & 64 & 32 & 512 & 16 & 128 & 8 & 256 & 32 & 128 & 64 & 512 \\
\hline
\end{tabular}

STM, streptomycin; NLD, nalidixic acid, BC, Bacillus cereus; BS, B. subtilis; EF, Enterococcus faecalis; MS, Mycobacterium smegmatis; SE, Staphylococcus epidermidis; SA, S. aureus; ECL, Enterobacter cloacae; EC, Escherichia coli; EA, Enterobacter aerogenes; PV, Proteus vulgaris; KO, Klebsiella oxytoca; KP, K. pneumonia; PM, Proteus mirabilis; PA, Pseudomonas aeruginosa 
troublesome and turn to nullify the effects of almost all antibiotics and antimicrobial options available [22].

These molecules form the bilayer membrane that controls and regulate the flux of molecules in the cells; the complex lipids contain of Gram-negative bacteria may prevent the easy diffusion of chemicals into the cytoplasm of the organisms, which may not be the case of Gram-positive cells. This, therefore, makes them more resistant to chemicals compared to Gram-positive bacteria.

\section{Antifungal activity}

In assessing the antifungal property of the synthesized Schiff bases, five Aspergillus representatives and two Fusarium strains were considered. Minimum fungicidal concentration (MFC) by broth dilution technique was used and results are compared with amphotericin B and nystatin used as positive controls (Table 5). The compounds showed moderate to greater antifungal activity against the studied strains and to some extent exhibited antifungal greater than the standard drugs used. All test compounds showed significant antifungal activity (MFC $15.6 \mu \mathrm{g} / \mathrm{mL}$ ) than amphotericin B (MFC $125 \mu \mathrm{g} / \mathrm{mL}$ ) against Aspergillus carbonarius. This infers them preference over amphotericin B. The test compounds also demonstrated high cytotoxic effect against Aspergillus flavus and A. carbonarius as they exhibited MFC 7.8 and $15.6 \mu \mathrm{g} / \mathrm{mL}$. Compound 3.c exhibited the highest fungicidal property from this series with MFC alternating between 7.8 and $15.6 \mu \mathrm{g} / \mathrm{mL}$ against the investigated strains. This could be due to the heterocyclic ring and the hydrophobic nature of the compound.

The interaction of synthetic chemical and natural occurring molecules with the microbial cell membrane is enhanced by their physicochemical properties. The passage or movement of chemicals and other molecules into the cytoplasm of a cell is controlled by the cell membrane via their components interacting with these molecules.
The hydrophobic nature of microbial cell membrane will drive in the molecule of same nature. Lipophilicity $(\log \mathrm{P})$ is an important factor that controls this phenomenon was determined. It is usually expected that a high clogP value will exhibit more antimicrobial potency but we observed in this study that the activity of these series of Schiff bases depended not on their experimental lipophilicity values but to other factors or parameters such as ligand's geometrical arrangement, polarity, and stability. The nitro $\left(-\mathrm{NO}_{2}\right)$ containing Compound 3.a exhibited better antibacterial activity than its fluorinate $\left(-\mathrm{OCF}_{3}\right)$ Compound 3.e both at the ortho position. However, their hydroxyl $(-\mathrm{OH})$ analogue, Compound 3.b demonstrated a greater fungicidal activity. The carboxyl and sulfonyl based compounds (3.d and 3.e) exerted good fungicidal activity against the studied fungi displaying an equipotent activity (MFC 7.8-15.6 $\mu \mathrm{g} / \mathrm{mL}$ ) against all tested strains except in A. flavus and A. niger where MFC $31.2 \mu \mathrm{g} / \mathrm{mL}$ was recorded (Table 5).

\section{Antimalarial activity}

The antiplasmodial activity of the Compounds (3.a-f) was studied in vitro against P. falciparum strain 3D7. Incubation of the parasites with the test compounds for $48 \mathrm{~h}$ revealed their antimalarial property. All tested compounds affected the respiratory processes of the parasites and induced a significant decrease in their growth causing complete cell death at the studied concentration. These Schiff bases reduced P. falciparum strain $3 \mathrm{D} 7$ growth by more than $\pm 50 \%$ at a single concentration of $50 \mu \mathrm{g} / \mathrm{mL}$ (Fig. 2). The lowest antimalarial activity exhibited by Compound 3.a, reduced the growth of P. falciparum strain 3D7 by 49\%. Compounds 3.c and 3.d were the most potent antiplasmodial compounds in this group and exhibited $95 \%$ and $85 \%$ growth inhibition respectively. The nitro, hydroxyl, and trifluoromethoxysubstituted compounds at position two (Compounds 3.a, 3.b and 3.f) have good antimalarial properties with

Table 5 Minimum fungicidal concentration (MFC) of Schiff bases 3.a-f

\begin{tabular}{|c|c|c|c|c|c|c|c|c|}
\hline \multirow[t]{2}{*}{ Strains code } & \multicolumn{6}{|c|}{ Test compounds with MFC ( $\mu \mathrm{g} / \mathrm{mL})$} & \multicolumn{2}{|c|}{ Standards ( $\mu \mathrm{g} / \mathrm{mL})$} \\
\hline & 3.a & 3.b & 3.c & 3.d & 3.e & 3.f & AMB & NYT \\
\hline ACA & 31.2 & 15.6 & 15.6 & 15.6 & 15.6 & 15.6 & 125 & $<8$ \\
\hline AFL & 31.2 & 31.2 & 15.6 & 15.6 & 31.2 & 7.8 & $>8$ & 16 \\
\hline AFU & 7.8 & 7.8 & 7.8 & 7.8 & 7.8 & 15.6 & 16 & 16 \\
\hline ANI & 15.6 & 31.2 & 15.6 & 15.6 & 31.2 & 31.2 & 16 & 62 \\
\hline APA & 31.2 & 31.2 & 7.8 & 15.6 & 15.6 & 15.6 & 62 & 16 \\
\hline FPR & 15.6 & 62.5 & 15.6 & 15.6 & 15.6 & 31.2 & 62 & $<8$ \\
\hline FVE & 62.5 & 62.5 & 62.5 & 62.5 & 62.5 & 62.5 & 16 & $<8$ \\
\hline
\end{tabular}

ACA, Aspergillus carbonarius; AFL, Aspergillus flavus; AFU, A. fumigatus; ANI, A. niger; APA, A. parasiticus; FPR, F. proliferatum; FVE, F. verticillioides; AMB, amphotericin B; NTY, nystatin 
comparable antiplasmodial activity against strain 3D7. Compounds 3.b and 3.f have the same potency against the investigated strain though no $\mathrm{IC}_{50}$ was recorded. The $\mathrm{IC}_{50}$ (smallest concentration of compounds that reduced by $50 \%$ the growth of the parasites) of Compounds 3.c and 3.d were found to be $\mathrm{IC}_{50} 26.96$ and $28.31 \mu \mathrm{g} / \mathrm{mL}$ respectively. Considering substitution at the fourth position of the aromatic ring, the carboxyl derivative Compound 3.d, have greater antimalarial activity compared to its sulfonate analogue Compound 3.e possibly due to the proton in ortho position. Compound 3.c stand out to be most potent antiplasmodial compound investigated in this group of Schiff bases. It is important to note that the highest activity of Compound 3.c could be due to the heterocyclic nature of the 2-aminopyrimidine. The nitrogen contain of the pyridine considerably enhanced the antimalarial activity of the compound and therefore suggests additional structure-activity relationship using the compound (3.c) as the parent material.

\section{Antitrypanosomal test}

The effects of the prepared Schiff bases on Trypanosoma parasites were assessed against $T$. bruce $i$ and data are presented in Fig. 2. All compounds were highly toxic to the studied strain except the sulfonate derivative Compound 3.e that showed $20 \%$ loss in parasite growth in comparison to more than $50 \%$ observed with others compounds (50-92\%). The nitro and hydroxyl derivatives (Compounds 3.a and 3.b) are highly effective against T. brucei compared to their trifluoromethoxy analogue Compound 3.f. It was observed that the antitrypanosomal potency of compounds with substitution in position 2 (3.a, 3.b and 3.f) depended on the type of substituent and followed this order 3.f, 3.a and 3.c with reference to their polarity.

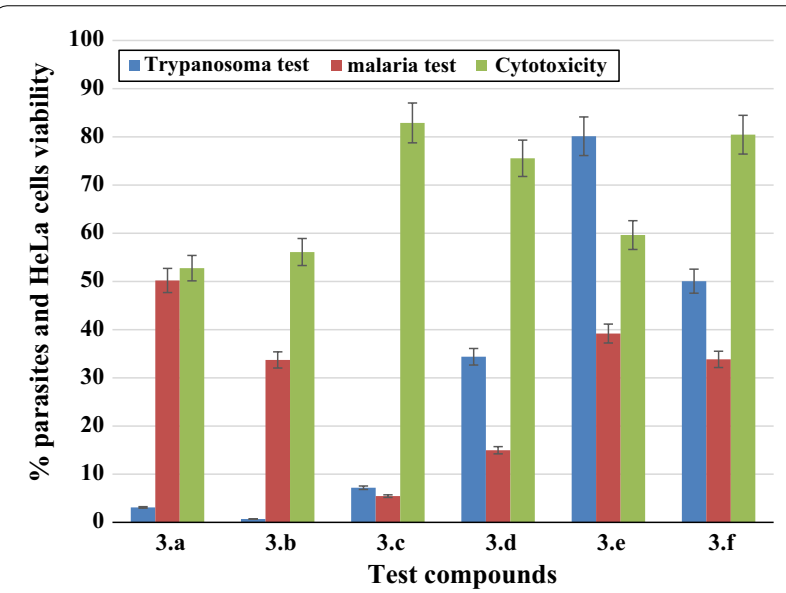

Fig. 2 Percentage viability of $P$. falciparum strain 3D7 and T. brucei after $48 \mathrm{~h}$ exposure to the synthesized Schiff bases, together with their cytotoxicity effects against Human cervix adenocarcinoma cells (HeLa)
Since chemical molecules alter cell growth by causing or inducing either cytoplasmic leakage [22], disruption of respiratory processes $[23,24]$, binding to DNA and/ or inhibit the process of replication. Cell death observed herein could also be attributed to active reactive oxygen species (ROS) induced by the tested compounds [25]. With no clear mechanism of action, the metabolic activity of the microorganism is altered by compound's polarity $\left(\mathrm{OCF}_{3}>\mathrm{NO}_{2}>\mathrm{OH}\right)$. Structure activity relationship (SAR) in drug discovery couple different parameters; structures, geometry arrangement, and substitution (cyclic and/acyclic) and much more [26]. The hydroxyl derivative Compound 3.b displayed the highest trypanocidal activity against $T$. brucei. The potency of this Compound 3.b could be assigned to the $-\mathrm{OH}$ substitution characterized by either keto-enol tautomeric exhibited in solid state and in solution [26, 27]. Again we observed a strong trypanocidal activity exhibited by Compound 3.c due to its pyridine contain. Pyrimidine substitution containing Schiff bases have also been recorded to exhibit antimicrobial activity against human pathogens [28-30]. This correlates well with our finding in this study.

\section{Cytotoxicity test}

Cytotoxicity of the compounds was evaluated against Human cervix adenocarcinoma cell (HeLa). The Schiff bases showed moderate to low toxicity against HeLa cells (Fig. 2). The percentage viability of the cells varies between 52 and $83 \%$ dependent on the compound. Compound 3.a was the most cytotoxic agent in this group with $48 \%$ cell growth inhibition. Compounds 3.c, $3 . d$ and 3.f are biocompatible with HeLa cells as they displayed low toxicity. The heterocyclic pyridine contain Compound 3.c has demonstrated the lowest toxic effect on HeLa cells $(<10 \%)$ and has demonstrated important antimalarial and antitrypanosomal activities. With a very low cytotoxic effect on HeLa, Compound 3.c stands out to be a very good antiparasitic agent and consideration to further evaluate the candidate drug against others cell lines is necessary.

\section{Conclusion}

A series of six novel Schiff base compounds with benzimidazole scaffold was successfully synthesized and their chemical structures were confirmed by UV-VIS, FTIR, elemental analysis, ${ }^{1} \mathrm{H}$ and ${ }^{13} \mathrm{C}$ NMR analysis. The biological applications of these compounds were studied against fourteen bacteria, seven fungi, and two parasites. The compounds have good antimicrobial activity against the studied microorganisms altering their metabolic activity and respiratory processes that lead to cell death. The newly synthesized Schiff bases have no cytotoxic effect against HeLa cell lines, and consideration for the 
use of these compounds as lead material for the further development of antibiotic agents is encouraged.

\section{Materials and methods Materials}

Sigma Aldrich's chemicals and reagents were purchased in South Africa and used without any additional treatment or conditioning. Benzamine derivatives such as $O$-nitroaniline, 2-aminophenol, 2-aminopyridine, $p$-aminobenzoic acid, 2-aminophenol- $p$-sulfonic acid, 2-trifluoromethoxyaniline were all purchased from the source. All microorganisms including fungi and bacteria were obtained from Davies Diagnostic South Africa. Starting material, Compound 1 (Oct-2-ynoic acid (1,3-dihydrobenzoimidazole-2-ylidene)amide) was donated by the Department of Applied Chemistry University of Johannesburg with details available online [31].

\section{Physical measurements}

Normalized spectral data were used to ascertain, and confirm the chemical structure of the synthesized benzimidazole Schiff bases. The percentage compositions of $\mathrm{C}, \mathrm{H}$ and $\mathrm{N}$ of the Schiff bases were determined by micro analytical method on a Flash 2000 Organic Elemental Analyzer. Fourier transform infrared (FTIR) spectra of the ligands were collected on a Spectrum 100, PerkinElmer FTIR spectrophotometer. Analysis on dried and moisture-free ligands was done on frequency range $4000-200 \mathrm{~cm}^{-1}$. The degradation point of the compounds was verified on an Electro thermal digital melting point apparatus that has a maximum heating capacity of $450{ }^{\circ} \mathrm{C} .{ }^{1} \mathrm{H}$ and ${ }^{13} \mathrm{C}$ NMR spectra of the ligands were recorded in DMSO- $\mathrm{d}_{6}$ on a Bruker $400 \mathrm{MHz}$ NMR Spectrometer operating at room temperature with tetramethylsilane (TMS) as the internal standard. Values of chemical shifts are giving in parts per million (ppm) throughout the study. A Shimadzu model UV-2540 spectrophotometer was used to record absorption spectra of the ligands suspended in DMSO at room temperature in the wavelength range of $200-800 \mathrm{~nm}$.

\section{Synthesis of Schiff bases 3.a-f}

All synthesis was achieved in hot ethanol by the condensation reaction of an equimolar mixture of substituted amines (2.a-f) and Compound $\mathbf{1}$ following the procedure documented by [32]. Compound $\mathbf{1}(0.3921 \mathrm{mmol})$ was dissolved in ethanol and maintained warm in silicon oil. The corresponding amines $(0.3921 \mathrm{mmol})$ were suspended in ethanol and added dropwise to the ethanoic solution maintained stirring and the mixture was refluxed for $4 \mathrm{~h}$ (Scheme 1). The colored solutions evaporated at room temperature under a fume hood and the precipitates thoroughly washed in methanol and kept dry in a desiccator.
$N-(1,3-D i h y d r o-b e n z o i m i d a z o l-2-y l i d e n e)-N^{\prime}$-(2-nitrophenyl)-oct-2-ynamidine (3.a) Compound 1 (100 mg: $0.3921 \mathrm{mmol}) ; O$-nitroaniline $(54.16 \mathrm{mg}: 0.3921 \mathrm{mmol})$; (yield, 78\%); yellow powder, $\mathrm{mp}=178.7{ }^{\circ} \mathrm{C}$; UV-VIS $(\mathrm{nm}), \max 232 ; 275$. FTIR- $\left(\mathrm{cm}^{-1}\right): 3414(-\mathrm{OH}), 3000$ $(\mathrm{C}-\mathrm{H}), 1652(\mathrm{C}=\mathrm{N}), 1438(\mathrm{C}=\mathrm{C}), 1011(\mathrm{C}-\mathrm{N}), 950$ $(\mathrm{C}-\mathrm{H}) .{ }^{1} \mathrm{HNMR}\left(400 \mathrm{MHz}, \mathrm{DMSO}-\mathrm{d}_{6}\right) \delta=8.06(1 \mathrm{H}, \mathrm{s}$, $\left.\mathrm{NO}_{2}-\mathrm{Ar}-\mathrm{H}\right), 7.95-7.93\left(1 \mathrm{H}, \mathrm{d}, J=8 \mathrm{~Hz}, \mathrm{NO}_{2}-\mathrm{Ar}-\mathrm{H}\right)$, $7.47-7.35\left(1 \mathrm{H}, \mathrm{m}, J=8 \mathrm{~Hz}, \mathrm{NO}_{2}-\mathrm{Ar}-\mathrm{H}\right), 7.25-7.22(2 \mathrm{H}$, $\mathrm{m}, \mathrm{Ar}-\mathrm{H}), 7.08-7.05(1 \mathrm{H}, \mathrm{m}, \mathrm{Ar}-\mathrm{H}), 7.00-6.98(1 \mathrm{H}, \mathrm{d}$, $J=8 \mathrm{~Hz}, \mathrm{Ar}-\mathrm{H}) 6.62-6.58(1 \mathrm{H}, \mathrm{t}, J=8 \mathrm{~Hz}, \mathrm{Ar}-\mathrm{H}), 3.97$ $(2 \mathrm{H}, \mathrm{s}, \mathrm{N}-\mathrm{H}), 2.25-2.21\left(2 \mathrm{H}, \mathrm{t}, J=8 \mathrm{~Hz}, \mathrm{C} \equiv \mathrm{CH}_{2}-\mathrm{CH}_{2}\right)$, 1.45-1.28 (6H, m, $\left.\mathrm{CH}_{2}-\mathrm{CH}_{2}-\mathrm{CH}_{2}\right), 0.86-0.32(3 \mathrm{H}, \mathrm{t}$, $\left.J=8 \mathrm{~Hz}, \mathrm{CH}_{3}-\mathrm{CH}_{2}\right) ;{ }^{13} \mathrm{CNMR}\left(400 \mathrm{MHz}, \mathrm{DMSO}-\mathrm{d}-{ }_{6}\right.$ ), $158.05(\mathrm{C}=\mathrm{N}), 152.83(\mathrm{C}=\mathrm{N}), 146.20(\mathrm{C}=\mathrm{C}-\mathrm{N}), 135.72$ $\left(\mathrm{NO}_{2}-\mathrm{C}=\mathrm{C}\right), \quad 132.41 \quad(\mathrm{C}=\mathrm{C}), 131.80 \quad(\mathrm{C}=\mathrm{C}), \quad 130.45$ $(\mathrm{C}=\mathrm{C}), 128.74(\mathrm{C}=\mathrm{C}), 125.37(\mathrm{C}=\mathrm{C}), 121.67(\mathrm{C}=\mathrm{C})$, $119.19(\mathrm{C}=\mathrm{C}), \quad 115.5(\mathrm{C}=\mathrm{C}), 111.74(\mathrm{C}=\mathrm{C}), 111.21$ $(\mathrm{C}=\mathrm{C}), 81.61(\mathrm{C} \equiv \mathrm{C}), 78.56(\mathrm{C} \equiv \mathrm{C}), 30.44\left(\mathrm{C} \equiv \mathrm{C}-\mathrm{CH}_{2}\right)$, 27.34 $\left(\mathrm{CH}_{2}-\mathrm{CH}_{2}\right), 21.61\left(\mathrm{CH}_{2}-\mathrm{CH}_{2}\right), 17.68\left(\mathrm{CH}_{2}-\mathrm{CH}_{2}\right)$ $13,83\left(\mathrm{CH}_{2}-\mathrm{CH}_{3}\right)$; Anal calcd for $\mathrm{C}_{21} \mathrm{H}_{21} \mathrm{~N}_{5} \mathrm{O}_{2} \%$ : C, 67.18; H, 5.64; N, 18.65; O, 8.52; Found: $\mathrm{C}, 67.57 ; \mathrm{H}, 6.08$; $\mathrm{N}, 18.32 ; \mathrm{O}, 8.09$.

$N$-(1,3-Dihydro-benzoimidazol-2-ylidene)-N'-(2-hydroxy -phenyl)-oct-2-ynamidine (3.b) Compound 1 (100 mg: $0.3921 \mathrm{mmol}$ ); 2-aminophenol (47.7 mg: $0.3921 \mathrm{mmol}$ ); (yield, 46\%); brown powder, $\mathrm{mp}=136.7-137.8{ }^{\circ} \mathrm{C}$; UVVIS $(\mathrm{nm}), \max 234 ; 286$. FTIR- $\left(\mathrm{cm}^{-1}\right): 3370(-\mathrm{OH})$, $2959(\mathrm{C}-\mathrm{H}), 1677(\mathrm{C}=\mathrm{N}), 1366(\mathrm{C}=\mathrm{C}), 1030(\mathrm{C}-\mathrm{N}), 825$ $(\mathrm{C}-\mathrm{H}) .{ }^{1} \mathrm{HNMR}\left(400 \mathrm{MHz}, \mathrm{DMSO}-\mathrm{d}_{6}\right) \delta=8.29(1 \mathrm{H}, \mathrm{s}$, $\mathrm{Ar}-\mathrm{OH}), 7.95(1 \mathrm{H}, \mathrm{s}, \mathrm{Ar}-\mathrm{H}), 7.39-7.35(2 \mathrm{H}, \mathrm{m}, \mathrm{Ar}-\mathrm{H})$, 6.63-6.61 (2H, m, Ar-H), 6.57-6.35 (2H, m, Ar-H), 4.61 $(2 \mathrm{H}, \mathrm{s}, \mathrm{N}-\mathrm{H}), 2.23-2.21\left(2 \mathrm{H}, \mathrm{t}, J=8 \mathrm{~Hz}, \mathrm{C} \equiv \mathrm{CH}_{2}-\mathrm{CH}_{-}\right)$, 1.45-1.29 (6H, m, $\left.\mathrm{CH}_{2}-\mathrm{CH}_{2}-\mathrm{CH}_{2}\right), 0.87-0.33(3 \mathrm{H}, \mathrm{t}$, $\left.J=8 \mathrm{~Hz}, \mathrm{CH}_{3}-\mathrm{CH}_{2}\right) ;{ }^{13} \mathrm{CNMR}\left(400 \mathrm{MHz}, \mathrm{DMSO}-\mathrm{d}-{ }_{6}\right)$, $157.89(\mathrm{C}=\mathrm{N}), 152.99(\mathrm{C}=\mathrm{N}), 144.00(\mathrm{C}=\mathrm{C}-\mathrm{N}), 136.49$ $(\mathrm{OH}-\mathrm{C}=\mathrm{C}), 132.79(\mathrm{C}=\mathrm{C}), 131.86(\mathrm{C}=\mathrm{C}), 130.85(\mathrm{C}=\mathrm{C})$, $129.74(\mathrm{C}=\mathrm{C}), 121.48(\mathrm{C}=\mathrm{C}), 119.47(\mathrm{C}=\mathrm{C}), 116.44$ $(\mathrm{C}=\mathrm{C}), 114.44(\mathrm{C}=\mathrm{C}), 114.38(\mathrm{C}=\mathrm{C}), 81.91(\mathrm{C} \equiv \mathrm{C}), 78.26$ $(\mathrm{C} \equiv \mathrm{C}), \quad 30.43 \quad\left(\mathrm{C} \equiv \mathrm{C}-\mathrm{CH}_{2}\right), \quad 27.36 \quad\left(\mathrm{CH}_{2}-\mathrm{CH}_{2}\right), 21.61$ $\left(\mathrm{CH}_{2}-\mathrm{CH}_{2}\right), 17.68\left(\mathrm{CH}_{2}-\mathrm{CH}_{2}\right), 13.83\left(\mathrm{CH}_{2}-\mathrm{CH}_{3}\right)$; Anal calcd for $\mathrm{C}_{21} \mathrm{H}_{21} \mathrm{~N}_{4} \mathrm{O} \%$ : C, 72.81; H, 6.40; N, 16.17; O, 4.62; Found: C, 72.08; H, 6.88; N, 16.67; O, 8.37.

$N$-(1,3-Dihydro-benzoimidazol-2-ylidene)-N'-pyridin -2-yl-oct-2-ynamidine (3.c) Compound 1 (100 mg: $0.3921 \mathrm{mmol}$ ); 2-aminopyridine (36.9 mg: $0.3921 \mathrm{mmol}$ ); (yield, 63\%); brown powder, $\mathrm{mp}=172.1{ }^{\circ} \mathrm{C}$; UV-VIS $(\mathrm{nm}), \max 234 ;$ 284. FTIR- $\left(\mathrm{cm}^{-1}\right)$ : $3423(-\mathrm{OH}), 2982$ $(\mathrm{C}-\mathrm{H}), 1685(\mathrm{C}=\mathrm{N}), 1438(\mathrm{C}=\mathrm{C}), 1034(\mathrm{C}-\mathrm{N}), 950$ $(\mathrm{C}-\mathrm{H}) .{ }^{1} \mathrm{HNMR}\left(400 \mathrm{MHz}, \mathrm{DMSO}-\mathrm{d}_{6}\right) \delta=8.35(1 \mathrm{H}$, s, Ar-N-CH), $8.07(1 \mathrm{H}, \mathrm{s}, \mathrm{Ar}-\mathrm{H}), 7.86(1 \mathrm{H}, \mathrm{s}, \mathrm{Ar}-\mathrm{H})$, 
7.44-7.33 (1H, m, Ar-H), 7.24-7.20 (1H, m, Ar-H), 7.06-7.03 (1H, s, Ar-H), 6.45-6.41 $(1 \mathrm{H}, \mathrm{d}, J=8 \mathrm{~Hz}$, Ar-H), $4.83(2 \mathrm{H}, \mathrm{s}, \mathrm{N}-\mathrm{H}), 2.22-2.18(2 \mathrm{H}, \mathrm{t}, J=8 \mathrm{~Hz}$, $\left.\mathrm{C} \equiv \mathrm{CH}_{2}-\mathrm{CH}_{-}\right)$, 1.89-1.87 (2H, d, J=8 Hz, $\mathrm{CH}_{2}-\mathrm{CH}_{2}-$ $\left.\mathrm{CH}_{2}\right), 1.42-1.40\left(2 \mathrm{H}, \mathrm{d}, J=8 \mathrm{~Hz}, \mathrm{CH}_{2}-\mathrm{CH}_{2}-\mathrm{CH}_{2}\right)$, $1.28-1.26\left(2 \mathrm{H}, \mathrm{d}, J=8 \mathrm{~Hz}, \mathrm{CH}_{2}-\mathrm{CH}_{2}\right) 0.84-0.80(3 \mathrm{H}, \mathrm{t}$, $\left.J=8 \mathrm{~Hz}, \mathrm{CH}_{3}-\mathrm{CH}_{2}\right) ;{ }^{13} \mathrm{CNMR}$ (400 MHz, DMSO-d- ${ }_{6}$ ), $172.18(\mathrm{~N}=\mathrm{C}-\mathrm{N}), 159.42(\mathrm{C}=\mathrm{N}), 158.29(\mathrm{C}=\mathrm{N}), 146.89$ $(\mathrm{C}=\mathrm{C}-\mathrm{N}), \quad 137.37 \quad(\mathrm{C}=\mathrm{C}=\mathrm{C}), \quad 132.38 \quad(\mathrm{C}=\mathrm{C}), \quad 131.79$ $(\mathrm{C}=\mathrm{C}), 130.43(\mathrm{C}=\mathrm{C}), 129.02(\mathrm{C}=\mathrm{C}), 128.73(\mathrm{C} \equiv \mathrm{C})$, $121.66(\mathrm{C}=\mathrm{C}), 111.97(\mathrm{C}=\mathrm{C}), 111.20(\mathrm{C}=\mathrm{C}), 108.66$ $(\mathrm{C}=\mathrm{C}), 81.07(\mathrm{C} \equiv \mathrm{C}), 78.93(\mathrm{C} \equiv \mathrm{C}), 30.44 \quad\left(\mathrm{C} \equiv \mathrm{C}-\mathrm{CH}_{2}\right)$, $27.41\left(\mathrm{CH}_{2}-\mathrm{CH}_{2}\right), 21.16\left(\mathrm{CH}_{2}-\mathrm{CH}_{2}\right), 17.68\left(\mathrm{CH}_{2}-\mathrm{CH}_{2}\right)$ $13,83\left(\mathrm{CH}_{2}-\mathrm{CH}_{3}\right)$; Anal calcd for $\mathrm{C}_{-20} \mathrm{H}_{21} \mathrm{~N}_{5} \%$ : C, 72.48; H, 6.39; N, 21.13; Found: C, 72.57; H, 6.34; N, 21.09.

4 - [ 1 - (1, 3-Dihydro-benzoimidazol-2-ylideneamino)-oct-2-ynylideneamino]-benzoic acid (3.d) Compound 1 (100 mg: $0.3921 \mathrm{mmol}$ ); p-aminobenzoic acid (53.7 mg: $0.3921 \mathrm{mmol}$ ); (yield, $73 \%$ ); white powder, $\mathrm{mp}=175.2{ }^{\circ} \mathrm{C}$; UV-VIS (nm), $\max$ 235; 275. FTIR-(cm $\left.{ }^{-1}\right): 3666(-\mathrm{OH}), 2955(\mathrm{C}-\mathrm{H}), 1684$ $(\mathrm{C}=\mathrm{N}), 1481(\mathrm{C}=\mathrm{C}), 1034(\mathrm{C}-\mathrm{N}), 817(\mathrm{C}-\mathrm{H}) .{ }^{1} \mathrm{HNMR}$ $\left(400 \mathrm{MHz}, \mathrm{DMSO}-\mathrm{d}_{6}\right) \delta=8.35(1 \mathrm{H}, \mathrm{s}, \mathrm{COOH}), 7.68-$ $7.67(1 \mathrm{H}, \mathrm{d}, J=8 \mathrm{~Hz} \mathrm{Ar}-\mathrm{H}), 7.66-7.24(1 \mathrm{H}, \mathrm{m}, \mathrm{Ar}-\mathrm{H})$, 7.20-7.17 (2H, m, Ar-H), 7.09-7.07 (2H, m, Ar-H), 6.71-6.69 (2H, m, Ar-H), 6.49-6.46 (2H, m, Ar-H), 4.26 $(2 \mathrm{H}, \mathrm{s}, \mathrm{N}-\mathrm{H}), 2.24-2.21\left(2 \mathrm{H}, \mathrm{t}, J=8 \mathrm{~Hz}, \mathrm{C} \equiv \mathrm{CH}_{2}-\mathrm{CH}_{-}\right)$, 1.44-1.41 (2H, d, $\left.J=8 \mathrm{~Hz}, \mathrm{CH}_{2}-\mathrm{CH}_{2}-\mathrm{CH}_{2}\right), 1.31-1.28$ $\left(2 \mathrm{H}, \mathrm{d}, J=8 \mathrm{~Hz}, \mathrm{CH}_{2}-\mathrm{CH}_{2}\right), 1.27-1.23(2 \mathrm{H}, \mathrm{d}, J=8 \mathrm{~Hz}$, $\left.\mathrm{CH}_{2}-\mathrm{CH}_{2}-\mathrm{CH}_{2}\right), \quad 0.85-0.82\left(3 \mathrm{H}, \mathrm{t}, J=8 \mathrm{~Hz}, \mathrm{CH}_{3}-\right.$ $\mathrm{CH}_{2}$ ); ${ }^{13} \mathrm{CNMR}\left(400 \mathrm{MHz}, \mathrm{DMSO}-\mathrm{d}-{ }_{6}\right), 169.8(\mathrm{C}=\mathrm{O})$, $157.65(\mathrm{C}=\mathrm{N}), 152.82(\mathrm{C}=\mathrm{N}), 151.41(\mathrm{C}=\mathrm{C}-\mathrm{N}), 133.57$ $(\mathrm{C}=\mathrm{C}=\mathrm{C}), 132.32(\mathrm{C}=\mathrm{C}), 131.22(\mathrm{C}=\mathrm{C}), 121.75(\mathrm{C}=\mathrm{C})$, $116.34(\mathrm{C}=\mathrm{C}), 114.63(\mathrm{C}=\mathrm{C}), 111.25(\mathrm{C}=\mathrm{C}), 110.22$ $(\mathrm{C}=\mathrm{C}), 82.11(\mathrm{C} \equiv \mathrm{C}), 78.33(\mathrm{C} \equiv \mathrm{C}), 30.44\left(\mathrm{C} \equiv \mathrm{C}-\mathrm{CH}_{2}\right)$, 27.34 $\left(\mathrm{CH}_{2}-\mathrm{CH}_{2}\right), 21.60\left(\mathrm{CH}_{2}-\mathrm{CH}_{2}\right), 17.70\left(\mathrm{CH}_{2}-\mathrm{CH}_{2}\right)$ $13,80\left(\mathrm{CH}_{2}-\mathrm{CH}_{3}\right)$; Anal calcd for $\mathrm{C}_{22} \mathrm{H}_{22} \mathrm{~N}_{4} \mathrm{O}_{2} \%$ : C, 70.57; $\mathrm{H}, 5.92$; N, 14.96, O, 8.55; Found: C, 71.04; H, 6.16; N, 14.12; O, 8.68.

4- [ 1 - (1,3-Dihydro-benzoimidazol-2-ylideneamino)-oct-2-ynylideneamino]-3-hydroxy-benzenesulfonic acid (3.e) Compound 1 (100 mg: $0.3921 \mathrm{mmol}$ ); 2-aminophenol-p-sulfonic acid (74.1 mg: $0.3921 \mathrm{mmol}$ ); (yield, 64\%); purplish powder, $\mathrm{mp}=147.1^{\circ} \mathrm{C}$; UV-VIS (nm), $\max 234 ; 284$. FTIR-( $\left.\mathrm{cm}^{-1}\right): 3297(-\mathrm{OH})$, $2966(\mathrm{C}-\mathrm{H}), 1678(\mathrm{C}=\mathrm{N}), 1367(\mathrm{C}=\mathrm{C}), 1033(\mathrm{C}-\mathrm{N}), 820$ $(\mathrm{C}-\mathrm{H}) .{ }^{1} \mathrm{HNMR}\left(400 \mathrm{MHz}, \mathrm{DMSO}-\mathrm{d}_{6}\right) \delta=10.10(1 \mathrm{H}, \mathrm{s}$, $\left.\mathrm{HSO}_{3}\right), 8.40(1 \mathrm{H}, \mathrm{s}, \mathrm{OH}-\mathrm{Ar}-\mathrm{H}), 8.23(1 \mathrm{H}, \mathrm{s}, \mathrm{Ar}-\mathrm{H}), 7.35-$ $7.30(1 \mathrm{H}, \mathrm{m}, \mathrm{Ar}-\mathrm{H}), 7.25$ (1H, s, Ar-H), 7.21-7.19 (1H, m, Ar-H), 7.10-7.08 (1H, d, J=8 Hz, Ar-H), 6.74-6.72 $(1 \mathrm{H}$, d, $J=8 \mathrm{~Hz}, \mathrm{Ar}-\mathrm{H}), 5.87(2 \mathrm{H}, \mathrm{s}, \mathrm{N}-\mathrm{H}), 2.33-2.24(2 \mathrm{H}, \mathrm{t}$,
$\left.J=8 \mathrm{~Hz}, \mathrm{C} \equiv \mathrm{CH}_{2}-\mathrm{CH}_{-}\right), 1.89-1.87\left(2 \mathrm{H}, \mathrm{d}, J=8 \mathrm{~Hz}, \mathrm{CH}_{2}-\right.$ $\left.\mathrm{CH}_{2}-\mathrm{CH}_{2}\right), 1.47-1.45\left(2 \mathrm{H}, \mathrm{d}, \mathrm{J}=8 \mathrm{~Hz}, \mathrm{CH}_{2}-\mathrm{CH}_{2}-\mathrm{CH}_{2}\right)$, 1.30-1.28 $\left(2 \mathrm{H}, \mathrm{t}, J=8 \mathrm{~Hz}, \mathrm{CH}_{2}-\mathrm{CH}_{2}\right), 0.86-0.83(3 \mathrm{H}, \mathrm{t}$, $\left.J=8 \mathrm{~Hz}, \mathrm{CH}_{3}-\mathrm{CH}_{2}\right) ;{ }^{13} \mathrm{CNMR}\left(400 \mathrm{MHz}, \mathrm{DMSO}-\mathrm{d}-{ }_{6}\right)$, $157.56(\mathrm{C}=\mathrm{N}), 152.86(\mathrm{C}=\mathrm{N}), 135.44(\mathrm{C}=\mathrm{C}-\mathrm{N}), 132.64$ $(\mathrm{C}=\mathrm{C}=\mathrm{C}), 131.79(\mathrm{C}=\mathrm{C}), 130.46(\mathrm{C}=\mathrm{C}), 129.16(\mathrm{C}=\mathrm{C})$, $128.74(\mathrm{C}=\mathrm{C}), \quad 121.89(\mathrm{C} \equiv \mathrm{C}), 121.62(\mathrm{C}=\mathrm{C}), 114.34$ $(\mathrm{C}=\mathrm{C}), 112.92(\mathrm{C}=\mathrm{C}), 112.43(\mathrm{C}=\mathrm{C}), 111.80 \quad \mathrm{C}=\mathrm{C})$, $111.27(\mathrm{C}=\mathrm{C}), 82.15(\mathrm{C} \equiv \mathrm{C}), 78.29(\mathrm{C} \equiv \mathrm{C}), 30.43(\mathrm{C} \equiv \mathrm{C}-$ $\left.\mathrm{CH}_{2}\right), 27.32\left(\mathrm{CH}_{2}-\mathrm{CH}_{2}\right), 21.59\left(\mathrm{CH}_{2}-\mathrm{CH}_{2}\right), 17.60\left(\mathrm{CH}_{2}-\right.$ $\left.\mathrm{CH}_{2}\right)$ 13,80 $\left(\mathrm{CH}_{2}-\mathrm{CH}_{3}\right)$; Anal calcd for $\mathrm{C}_{-21} \mathrm{H}_{22} \mathrm{~N}_{4} \mathrm{O}_{4} \mathrm{~S} \%: \mathrm{C}$, 59.14; H, 5.20; N, 13.14; O, 15.01; S, 7.52. Found: C, 59.62; H, 4.98; N, 13.21; O, 14.68; S, 7.51.

N-(1,3-Dihydro-benzoimidazol-2-ylidene)-N'-(2-trif luoromethoxy-phenyl)-oct-2-ynamidine (3.f) Compound 1 (100 mg: $0.3921 \mathrm{mmol}) ;$ 2-aminopyridine (36.9 mg: $0.3921 \mathrm{mmol}$ ); (yield, 63\%); brown powder, $\mathrm{mp}=172.1{ }^{\circ} \mathrm{C}$; UV-VIS (nm), $\max 234 ; 284 .{ }^{1} \mathrm{HNMR}$ $\left(400 \mathrm{MHz}, \mathrm{DMSO}-\mathrm{d}_{6}\right) \delta=8.07(1 \mathrm{H}, \mathrm{s}, \mathrm{Ar}-\mathrm{H}), 7.21(1 \mathrm{H}$, $\mathrm{m}, \mathrm{Ar}-\mathrm{H}), 7.06-7.04(1 \mathrm{H}, \mathrm{m}, \mathrm{Ar}-\mathrm{H}), 6.45-6.41(1 \mathrm{H}$, d, $J=8 \mathrm{~Hz}, \mathrm{Ar}-\mathrm{H}), 4.50(2 \mathrm{H}, \mathrm{s}, \mathrm{N}-\mathrm{H}), 2.24-2.21(2 \mathrm{H}, \mathrm{t}$, $\left.J=8 \mathrm{~Hz}, \mathrm{C} \equiv \mathrm{CH}_{2}-\mathrm{CH}_{-}\right)$, $1.44-1.39\left(2 \mathrm{H}, \mathrm{m}, \mathrm{CH}_{2}-\mathrm{CH}_{2}-\right.$ $\left.\mathrm{CH}_{2}\right), 1.33-1.31\left(2 \mathrm{H}, \mathrm{d}, J=8 \mathrm{~Hz}, \mathrm{CH}_{2}-\mathrm{CH}_{2}-\mathrm{CH}_{2}\right)$, 1.29-1.24 (2H, m, $\left.\mathrm{CH}_{2}-\mathrm{CH}_{2}\right)$ 0.86-0.83 (3H, t, $J=8 \mathrm{~Hz}$, $\mathrm{CH}_{3}-\mathrm{CH}_{2}$ ); ${ }^{13} \mathrm{CNMR}$ (400 MHz, DMSO-d- ${ }_{6}$ ), 172.18 $(\mathrm{N}=\mathrm{C}-\mathrm{N}), 159.42(\mathrm{C}=\mathrm{N}), 158.29(\mathrm{C}=\mathrm{N}), 146.89(\mathrm{C}=\mathrm{C}-$ $\mathrm{N}), 137.37(\mathrm{C}=\mathrm{C}=\mathrm{C}), 132.38(\mathrm{C}=\mathrm{C}), 131.79(\mathrm{C}=\mathrm{C})$, $130.43(\mathrm{C}=\mathrm{C}), 129.02(\mathrm{C}=\mathrm{C}), 128.73(\mathrm{C} \equiv \mathrm{C}), 121.66$ $(\mathrm{C}=\mathrm{C}), 111.97(\mathrm{C}=\mathrm{C}), 111.20(\mathrm{C}=\mathrm{C}), 108.66(\mathrm{C}=\mathrm{C})$, $81.07(\mathrm{C} \equiv \mathrm{C}), \quad 78.93(\mathrm{C} \equiv \mathrm{C}), 30.44 \quad\left(\mathrm{C} \equiv \mathrm{C}-\mathrm{CH}_{2}\right), \quad 27.41$ $\left(\mathrm{CH}_{2}-\mathrm{CH}_{2}\right), 21.16\left(\mathrm{CH}_{2}-\mathrm{CH}_{2}\right), 17.68\left(\mathrm{CH}_{2}-\mathrm{CH}_{2}\right) 13,83$ $\left(\mathrm{CH}_{2}-\mathrm{CH}_{3}\right)$; Anal calcd for $\mathrm{C}_{22} \mathrm{H}_{21} \mathrm{~F}_{3} \mathrm{~N}_{4} \mathrm{O} \%$ : C, 63.76; $\mathrm{H}$, 5.11; F, 13.75; N, 13.52; O, 3.86 Found: C, 64.17; H, 5.78; N, 13.12; F, 13.75; O, 3.18.

\section{Biological activity Antibacterial test}

The synthesized ligands were tested in vitro against Gram negative bacterial species Enterobacter cloacae (ECL) (ATCC13047), E. coli (EC) (ATCC25922), Enterobacter aerogenes, (EA) (ATCC13048), Proteus vulgaris (PV) (ATCC6380), Klebsiella oxytoca (KO) (ATCC8724), K. pneumonia (KP) (ATCC13882), Proteus mirabilis (PM) (ATCC7002) and Pseudomonas aeruginosa (PA) (ATCC27853) and Gram positive bacterial representatives Bacillus cereus (BC) (ATCC10876), B. subtilis (BS) (ATCC19659), Enterococcus faecalis (EF) (ATCC13047), Mycobacterium smegmatis (MS) (MC2155), Staphylococcus epidermidis (SE) (ATCC14990) and S. aureus (SA) (ATCC25923) by microdilution method. The minimum inhibitory contractions (MIC) were determined 
according to reference method M38-A2 [33]. For comparison purposes, streptomycin and nalidixic acid were used as positive controls. Fresh bacterial cultures were harvested from an overnight bacterial growth and diluted in nutrient broth to match the $0.5 \mathrm{McF}$ arland standards which are equivalent to $1 \times 10^{5} \mathrm{cfu} / \mathrm{mL}$. This suspension $(100 \mu \mathrm{L})$ was then seeded under aseptic conditions in a 96-well plate containing $100 \mu \mathrm{L}$ of serially diluted test compounds concentrations of $500250,125,62.531 .2$, 15.6 and $7.8 \mu \mathrm{g} / \mathrm{mL}$. The plates were then incubated at $30{ }^{\circ} \mathrm{C}$ for $24 \mathrm{~h}$. Life or death cells were verified calorimetrical by addition of resazurin dye $(0.02 \%)$ which is metabolized enzymatically to produce a pink resoforin precipitate in the presence of viable cells and remains blue in death cells. MIC of each ligand are recorded and presented together with the standards.

\section{Antifungal test}

Antifungal activity of the ligands was done the same way as mentioned above. To assess the effect of the synthesized Schiff base compounds against fungi (A. carbonarius, A. flavus, A. fumigatus, A. parasiticus, A. niger, Fusarium proliferatum and $F$. verticillioides), different ligand's concentrations (500, 250, 125, 62.5 31.2, 15.6 and $7.8 \mu \mathrm{g} / \mathrm{mL}$ ) were prepared and incubated with fresh fungal spores $\left(1 \times 10^{5}\right.$ spores $\left./ \mathrm{mL}\right)$ in a 96 -well plates following the reference method for broth dilution antifungal susceptibility testing of filamentous fungi by [33]. Amphotericin B and nystatin were used throughout this study as standards fungicidal drugs. Following $72 \mathrm{~h}$ incubation, the plates were taking out and flooded with $10 \mu \mathrm{L}$ $(0.02 \%)$ of resazurin and the small concentrations that induced fungal cell death were considered as minimum fungicidal concentration (MFC).

\section{Antiplasmodial assay}

Malaria is a infectious disease caused by five different Plasmodium species (P. falciparum, P. vivax, P. malariae, $P$. ovale, and $P$. knowlesi) that are responsible for over 65 5000 deaths in children below the age of five years and pregnant women [34]. To evaluate the antimalarial property of the ligands synthesized, the most fatal transmitting vector ( $P$. falciparum strain 3D7) was selected. The antiplasmodial activity of the ligands was done by measuring the activity of the parasite's lactate dehydrogenase enzyme, comparing it with Chloroquine (IC- 50 0.01-0.05 $\mu \mathrm{M}$ ) used as a positive control. Plasmodia parasites were cultured at $37{ }^{\circ} \mathrm{C}$ under an atmosphere of $5 \% \mathrm{CO}_{2}, 5 \% \mathrm{O}_{2}, 90 \% \mathrm{~N}_{2}$ in sealed T25 or T75 culture flasks for $48 \mathrm{~h}$ in RPMI 1640 media $(2 \mathrm{mM} \mathrm{L}$-glutamine and $25 \mathrm{mM}$ Hepes (Lonza) supplemented with 5\% Albumax II, $20 \mathrm{mM}$ glucose, $0.65 \mathrm{mM}$ hypoxanthine, $60 \mu \mathrm{g} /$ $\mathrm{mL}$ gentamycin and $2-4 \%$ hematocrit human red blood cells. Two days later, the test compounds were dissolved in DMSO to the working concentration of $20 \mu \mathrm{g} / \mathrm{L}$ and $140 \mu \mathrm{L}$ was transferred in 96-well plates with was then seeded with the fresh cultures prepared containing $2 \%$ parasites and incubated for another $48 \mathrm{~h}$. Following this incubation period, $20 \mu \mathrm{L}$ of this mixture was added to fresh 96-well plates conditioned with $125 \mu \mathrm{L}$ of Malsat and NBT/PES that measures microscopically $\left(\lambda_{620}\right)$ the amount of purple products formed in the presence of the parasite lactate dehydrogenase (pLDH).

\section{Antitrypanosomal assay}

Trypanosomiasis or African sleeping sickness is an infectious disease caused by Trypanosoma brucei that when under looked also increases the rate of mortality in tropical hemisphere [35]. In assessing the trypanocidal property of the synthesized compounds, the ligands were suspended in DMSO to have $50 \mu \mathrm{g} / \mathrm{mL}$ of product and $140 \mu \mathrm{L}$ of this solution was transferred into 96-well plate seeded with $2 \%$ cultures of $T$. brucei. The mixture was then incubated for $48 \mathrm{~h}$ at $37{ }^{\circ} \mathrm{C}$ under an atmosphere of $5 \% \mathrm{CO}_{2}, 5 \% \mathrm{O}_{2}, 90 \% \mathrm{~N}_{2}$. After $48 \mathrm{~h}$ incubation, resazurin based reagent was used to obtain the total number of parasites surviving ligand's exposure and the results are compared with Pentamidine standard drug used as positive control.

\section{Cytotoxicity assay}

The toxicity of the ligands was also verified against Human cervix adenocarcinoma cell (HeLa). This was achieved by mixing equal volume of test compounds $(50 \mu \mathrm{g} / \mathrm{mL})$ with Hela cells $\left(6.7 \times 10^{4} \mathrm{cell} / \mathrm{mL}\right)$ and allowed the mixture to stand at $37{ }^{\circ} \mathrm{C}$ under an atmosphere of $5 \% \mathrm{CO}_{2}, 5 \% \mathrm{O}_{2}, 90 \% \mathrm{~N}_{2}$ for a maximum of $48 \mathrm{~h}$. The numbers of Hela cells that survive compounds exposure were also determined by using resazurin based reagent and reading resorufin fluorescence in a multi-well plate reader.

\section{Supplementary information}

Supplementary information accompanies this paper at https://doi. org/10.1186/s13065-019-0642-3.

Additional file 1: Fig. S1. FTIR spectrum of Schiff base Compound 3.a. Fig. S2. FTIR spectrum of Schiff base Compound 3.b. Fig. S3. FTIR spectrum of Schiff base Compound 3.c. Fig. S4. FTIR spectrum of Schiff base Compound 3.d. Fig. S5. FTIR spectrum of Schiff base Compound 3.e. Fig. S6. FTIR spectrum of Schiff base Compound 3.f. Fig. S7. Normalized UV-vis absorption spectrum of Schiff base 3.a. Fig. S8. Normalized UV-vis absorption spectrum of Schiff base 3.b. Fig. S9. Normalized UV-vis absorption spectrum of Schiff base 3.c. Fig. S10. Normalized UV-vis absorption spectrum of Schiff base 3.d. Fig. S11. Normalized UV-Vis absorption spectrum of Schiff base 3.e. Fig. S12. Normalized UV-Vis absorption spectrum of Schiff base 3.f. Fig. S13. ${ }^{1} \mathrm{H}$ NMR spectrum of Schiff base Compound 3.a. Fig. S14. ${ }^{13} \mathrm{C}$ NMR spectrum of Schiff base Compound 3.a. Fig. S15. 'H NMR spectrum of Schiff base Compound 3.b 
Fig. S16. ${ }^{13} \mathrm{C}$ NMR spectrum of Schiff base Compound 3.b. Fig. S17. ${ }^{1}$ NMR spectrum of Schiff base Compound 3.c. Fig. S18. ${ }^{13} \mathrm{C}$ NMR spectrum of Schiff base Compound 3.c. Fig. S19. ${ }^{1} \mathrm{H}$ NMR spectrum of Schiff base Compound 3.d. Fig. S20. ${ }^{13} \mathrm{C}$ NMR spectrum of Schiff base Compound 3.d. Fig. S21. ${ }^{1} H$ NMR spectrum of Schiff base Compound 3.e. Fig. S22. ${ }^{13} \mathrm{C}$ NMR spectrum of Schiff base compound 3.e. Fig. S23. ${ }^{1} \mathrm{H}$ NMR spectrum of Schiff base Compound 3.f. Fig. S24. ${ }^{13} \mathrm{C}$ NMR spectrum of Schiff base Compound 3.f.

\section{Abbreviations}

ACA: Aspergillus carbonarius; AFL: Aspergillus flavus; AFU: Aspergillus fumigatus; AMB: amphotericin B; ANI: Aspergillus niger; APA: Aspergillus parasiticus; Ar-H: aromatic protons; $B C$ : Bacillus cereus; $B S$ : Bacillus subtilis; C: carbon; $\mathrm{Cfu} / \mathrm{mL}$ : colony forming unit per milliliter; clogP: lipophilicity; $\mathrm{Cm}^{-1}$ : wavenumber; ${ }^{13} \mathrm{C}$ NMR: carbon nuclear magnetic resonance spectroscopy; $\mathrm{CO}_{2}$ : carbon dioxide; $d$ : doublet; DMSO: dimethyl sulfoxide; DMSO- $\mathrm{d}_{6}$ : deutoriated dimethyl sulfoxide; DNA: deoxyribose nucleoside triphosphate; EA: Enterobacter aerogenes; EC: Escherichia coli; ECL: Enterobacter cloacae; EF: Enterococcus faecalis; FPR: Fusarium proliferatum; FVE: Fusarium verticillioides; FTIR: Fourier Transform infrared; $\mathrm{g} / \mathrm{mol}$ : gram per mole; $\mathrm{IC}_{50}$ : smallest concentration of compounds that reduced by $50 \%$ the growth of the parasites; $\mathrm{H}$ : hydrogen; $\mathrm{h}$ : hour; ${ }^{1} \mathrm{H}$ NMR: proton nuclear magnetic resonance spectroscopy; HeLa: human cervix adenocarcinoma cells; $\mathrm{Hz}$ : hertz; $j$ : the coupling constant, $\mathbf{J}$ is a measure of the interaction between a pair of protons; KO: Klebsiella oxytoca; KP: Klebsiella pneumonia; m: multiplet; MFC: minimum fungicidal concentration; mg: milli gram; MIC: minimum inhibitory concentration; $\mathrm{MHz}$ : mega hertz; mmol: milli mole; Mp: melting point; MS: Mycobacterium smegmatis; MW: molecular weight; $\mathrm{N}$ : nitrogen; $\mathrm{nm}$ : nanometer; NLD: nalidixic acid; NMR: nuclear magnetic resonance spectroscopy; NTY: nystatin; O: oxygen (atom); $\mathrm{O}_{2}$ : oxygen (gas); PA: Pseudomonas aeruginosa; pLDH: parasite lactate dehydrogenase enzyme; PM: Proteus mirabilis; Ppm: parts per million; PV: Proteus vulgaris; RPMI: Roswell Park Memorial Institute; ROS: reactive oxygen species; S: sulfur; s: Singlet; SA: Staphylococcus aureus; SAR: structure activity relationship; SE: Staphylococcus epidermidis; STM: Streptomycin; t: triplet; TMS: tetramethylsilane; UV-VIS: ultraviolet visible light; $\mu \mathrm{g} / \mathrm{mL}$ : microgram per milli liter; $\mu \mathrm{L}$ : microliter; $\mu \mathrm{M}$ : micromole.

\section{Acknowledgements}

We are very thankful to the University of Johannesburg, the South African Medical Research Council (MRC) and the National Treasury (Rhodes University) under "Sandisa Imbewu".

\section{Authors' contributions}

PBN and DTN conceptualized, discussed and developed the idea and all laboratory activities including preparation, synthesis, characterisation and write up carried out by TYF under the continuous and rigorous supervision of MII. All the authors participated in the write up and discussion of the manuscript at any developmental stage and owned the right to authorship. All authors read and approved the final manuscript.

\section{Funding}

The authors would like to thank the University of Johannesburg Global Excellence and Stature (GES) program for their financial support (allowance) and the National Research Foundation (NRF) via the Research and Technology Fund (Ref: RTF150414117193) for their financial assistance in data analysis.

\section{Availability of data and materials}

All data generated or analysed during this study are included in this published article [and its Additional file 1].

\section{Competing interests}

The authors declare that they have no competing interests.

\section{Author details}

1 Department of Biotechnology and Food Technology, University of Johannesburg, Doornfontein Campus, P.O. Box 17011, Johannesburg 2028, South Africa.

${ }^{2}$ Department of Applied Chemistry, University of Johannesburg, Doornfontein Campus, P.O. Box 17011, Johannesburg 2028, South Africa.
Received: 26 July 2018 Accepted: 19 October 2019

Published online: 09 November 2019

\section{References}

1. McAloon CJ, Boylan LM, Hamborg T et al (2016) The changing face of cardiovascular disease 2000-2012: an analysis of the world health organisation global health estimates data. Int J Cardiol 224:256-264

2. Kajal A, Bala S, Kamboj S et al (2013) Schiff bases: a versatile pharmacophore. J Catal 2013:1-14

3. Selwin Joseyphus R, Shiju C, Joseph J et al (2014) Synthesis and characterization of metal complexes of Schiff base ligand derived from imidazole-2-carboxaldehyde and 4-aminoantipyrine. Spectrochim Acta A Mol Biomol Spectrosc 133:149-155

4. Hranjec M, Starčević K, Pavelić SK et al (2011) Synthesis, spectroscopic characterization and antiproliferative evaluation in vitro of novel Schiff bases related to benzimidazoles. Eur J Med Chem 46:2274-2279

5. Abonia R, Cortés E, Insuasty B et al (2011) Synthesis of novel 1,2,5-trisubstituted benzimidazoles as potential antitumor agents. Eur J Med Chem 46:4062-4070

6. Neochoritis CG, Zarganes-Tzitzikas T, Tsoleridis CA et al (2011) One-pot microwave assisted synthesis under green chemistry conditions, antioxidant screening, and cytotoxicity assessments of benzimidazole Schiff bases and pyrimido[1,2-a]benzimidazol-3(4H)-ones. Eur J Med Chem 46:297-306. https://doi.org/10.1016/j.jmech.2010.11.018

7. Kumaravel G, Raman N (2017) A treatise on benzimidazole based Schiff base metal(II) complexes accentuating their biological efficacy: spectroscopic evaluation of DNA interactions, DNA cleavage and antimicrobial screening. Mater Sci Eng C 70:184-194. https://doi.org/10.1016/j. msec.2016.08.069

8. Paul A, Anbu S, Sharma G et al (2015) Synthesis, DNA binding, cellular DNA lesion and cytotoxicity of a series of new benzimidazole-based Schiff base copper(II) complexes. Dalton Trans 44:19983-19996

9. Zhang L, Addla D, Ponmani J et al (2016) Discovery of membrane active benzimidazole quinolones-based topoisomerase inhibitors as potential DNA-binding antimicrobial agents. Eur J Med Chem 111:160-182

10. Weijie S, Tao Z, Dongmei $S$ et al (2016) Synthesis and biological activity of novel benzimidazole derivatives as potential antifungal agents. J Pestic Sci 41:15-19

11. Vicini P, Incerti M, Doytchinova IA et al (2006) Synthesis and antiproliferative activity of benzo[d]isothiazole hydrazones. Eur J Med Chem 41:624-632

12. Fu X-B, Lin Z-H, Liu H-F, Le X-Y (2014) A new ternary copper(II) complex derived from 2-(2'-pyridyl)benzimidazole and glycylglycine: synthesis, characterization, DNA binding and cleavage, antioxidation and HSA interaction. Spectrochim Acta A Mol Biomol Spectrosc 122:22-33

13. Song W-J, Cheng J-P, Jiang D-H et al (2014) Synthesis, interaction with DNA and antiproliferative activities of two novel $\mathrm{Cu}(\mathrm{II})$ complexes with Schiff base of benzimidazole. Spectrochim Acta A Mol Biomol Spectrosc 121:70-76

14. Singh M, Tandon V (2011) Synthesis and biological activity of novel inhibitors of topoisomerase l: 2-aryl-substituted 2-bis-1H-benzimidazoles. Eur J Med Chem 46:659-669

15. Hranjec M, Starčević K, Piantanida I et al (2008) Synthesis, antitumor evaluation and DNA binding studies of novel amidino-benzimidazolyl substituted derivatives of furyl-phenyl- and thienyl-phenyl-acrylates, naphthofurans and naphthothiophenes. Eur J Med Chem 43:2877-2890

16. Sedic M, Poznic M, Gehrig P et al (2008) Differential antiproliferative mechanisms of novel derivative of benzimidazo[1,2-]quinoline in colon cancer cells depending on their p53 status. Mol Cancer Ther 7:2121-2132

17. Singh G, Kaur M, Chander M (2013) Benzimidazoles: the latest information on biological activities. Int Res J Pharm 4:82-87

18. Batista RMF, Costa SPG, Belsley M, Raposo MMM (2007) Synthesis and second-order nonlinear optical properties of new chromophores containing benzimidazole, thiophene, and pyrrole heterocycles. Tetrahedron 63:9842-9849

19. Mateus A, Gordon LJ, Wayne GJ et al (2017) Prediction of intracellular exposure bridges the gap between target- and cell-based drug discovery. Proc Natl Acad Sci 114:E6231-E6239 
20. Mai-Prochnow A, Clauson M, Hong J, Murphy AB (2016) Gram positive and Gram negative bacteria differ in their sensitivity to cold plasma. Sci Rep 6:38610. https://doi.org/10.1038/srep38610

21. Dever LA, Dermody TS (1991) Mechanisms of bacterial resistance to antibiotics. Arch Intern Med 151:886-895

22. Ventola CL (2015) The antibiotic resistance crisis: part 1: causes and threats. P T Peer-Rev J Formul Manag 40:277-283

23. An T, Sun H, Li G et al (2016) Differences in photoelectrocatalytic inactivation processes between E. coli and its isogenic single gene knockoff mutants: destruction of membrane framework or associated proteins? Appl Catal B Environ 188:360-366

24. Jastroch M, Divakaruni AS, Mookerjee S et al (2010) Mitochondrial proton and electron leaks. Essays Biochem 47:53-67

25. Gaunt LF, Beggs CB, Georghiou GE (2006) Bactericidal action of the reactive species produced by gas-discharge nonthermal plasma at atmospheric pressure: a review. IEEE Trans Plasma Sci 34:1257-1269

26. Guha R (2013) On exploring structure-activity relationships. In: Kortagere $\mathrm{S}$ (ed) In silico models for drug discovery. Humana Press, Totowa, pp 81-94

27. Fita P, Luzina E, Dziembowska T et al (2005) Keto-enol tautomerism of two structurally related Schiff bases: direct and indirect way of creation of the excited keto tautomer. Chem Phys Lett 416:305-310

28. Hisaindee S, Al-Kaabi L, Ajeb S et al (2015) Antipathogenic effects of structurally-related Schiff base derivatives: structure-activity relationship. Arab J Chem 8:828-836

29. Wang $Y-Y, X u$ F-Z, Zhu Y-Y et al (2018) Pyrazolo[3,4-d]pyrimidine derivatives containing a Schiff base moiety as potential antiviral agents. Bioorg Med Chem Lett 28:2979-2984
30. Kumar S, Lim SM, Ramasamy K et al (2017) Synthesis, molecular docking and biological evaluation of bis-pyrimidine Schiff base derivatives. Chem Cent J 11:89. https://doi.org/10.1186/s13065-017-0322-0

31. Wahe H, Asobo PF, Cherkasov RA, et al (2003) Heterocycles of biological importance: part 6 . The formation of novel biologically active pyrimido[1,2-a]benzimidazoles from electron deficient alkynes and 2-aminobenzimidazoles. Arkivoc. 170

32. Yousif E, Majeed A, Al-Sammarrae K et al (2013) Metal complexes of Schiff base: preparation, characterization and antibacterial activity. Arab J Chem 10:1639-1644

33. CLSI (2008) Clinical, Laboratory Standards Institute. Reference method for broth dilution antifungal susceptibility testing of filamentous fungi, 2nd edn. CLSI, Wayne

34. Sharma M, Chauhan K, Srivastava RK et al (2014) Design and synthesis of a new class of 4-aminoquinolinyl- and 9-anilinoacridinyl Schiff base hydrazones as potent antimalarial agents. Chem Biol Drug Des 84:175-181

35. Aksoy S, Buscher $P$, Lehane M et al (2017) Human African trypanosomiasis control: achievements and challenges. PLoS Negl Trop Dis 11:e0005454

\section{Publisher's Note}

Springer Nature remains neutral with regard to jurisdictional claims in published maps and institutional affiliations.
Ready to submit your research? Choose BMC and benefit from:

- fast, convenient online submission

- thorough peer review by experienced researchers in your field

- rapid publication on acceptance

- support for research data, including large and complex data types

- gold Open Access which fosters wider collaboration and increased citations

- maximum visibility for your research: over $100 \mathrm{M}$ website views per year

At $\mathrm{BMC}$, research is always in progress.

Learn more biomedcentral.com/submissions 